\title{
Objektivitet i avhør
}

\section{Avhør av fornærmede i straffesaker i Norge}

Høgskolelektor og stipendiat Kristina Kepinska Jakobsen, professor Ulf Stridbeck og dr.polit. Åse Langballe

Kristina Kepinska Jakobsen, cand.psych., Københavns Universitet 2003. Siden 2012 høgskolelektor ved Politih øgskolen i Oslo. Doktorgradsstipendiat ved Institutt for kriminologi og rettssosiologi, Juridisk fakultet, UiO. Epost: krijak@phs.no

Ulf Stridbeck, fil.kand., Universitetet i Göteborg 1981, jur.kand. Lunds Universitet 1981, juris dr., Juridisk fakultet, Lunds Universitet 1992. Siden 1997 professor dr. juris ved Universitetet i Oslo.

Åse Langballe, cand.spes.ped. 1988. Dr.polit., Institutt for spesialpedagogikk, UiO 2004. Forsker II ved Nasjonalt kunnskapssenter om vold og traumatisk stress, seksjon barn og unge (NKVTS) 2004-2016. Pensjonert og timetilsatt ved NKVTS fra 2017.

\section{Sammendrag}

Objektivitet er en av rettssikkerhetens mest fundamentale prinsipper og gjelder for hele straffesakskjeden fra mistanke om straffbar handling til dom. Kravet om objektivitet henger sammen med den materielle sannhets prinsipp - at straffesaken fär et objektivt riktig resultat. I politiets opplaring fors $\phi$ kes objektiviteten ivaretatt ved en åpen, hypotesetestende tilnarming og ved å unngå å påvirke den avhфrtes forklaring, ved primart å benytte åpne spфrsmål. Hvordan objektivitetskravet operasjonaliseres av politiet under avhфr av fornaermede, er imidlertid uutforsket. Formålet med denne studien er å unders $\phi k e$ hvordan politiet praktiserer objektivitetskravet når de avhфrer

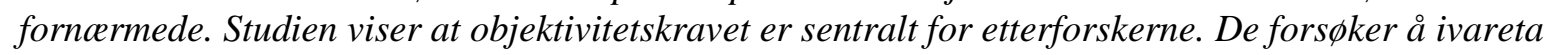
objektiviteten ved å vare upartiske, unngå å påvirke og holde en emosjonell distanse. Samtidig фnsker de å vare empatiske. Balansegangen mellom objektivitet og empati kan føre til kommunikative dilemmaer i avhфrerrollen. Det vil derfor bli analysert og diskutert hvordan kravene om objektivitet og empati håndteres. Vi har brukt to datakilder: 19 lyd-og bildeavhфr av ungdommer som overlevde terrorangrepet på Utøya 22. juli 2011, og intervjuer av de 17 etterforskerne som har gjennomført de 19 avhфrene. ${ }^{1}$

Nøkkelord: objektivitet, avhфr, fornarmede, KREATIV, kommunikative dilemmaer, empati

\footnotetext{
${ }^{1}$ Takk til to fagfeller med særdeles gode innspill. Artikkelen er altså fagfellevurdert (red.).
} 


\section{Innledning}

Generelt har objektivitet, ifølge ordbokdefinisjonen, ${ }^{2}$ å gjøre med saklighet og upartiskhet. I en rettsstats maktut $\varnothing$ velse er objektivitet en grunnleggende verdi. I strafferettslig sammenheng betyr objektivitetskravet at politi, påtalemyndighet og domstol skal være saklige og upartiske i sine vurderinger. Kravet om objektivitet henger sammen med den materielle sannhets prinsipp - at straffesaken får et objektivt riktig resultat. Den materielle sannhets prinsipp er særlig uttrykt i rettens plikt til å sørge for straffesakens riktige og fullstendige opplysning. ${ }^{3}$ I det hele tatt er objektivitet en forutsetning for å realisere straffeprosessens ideal om riktige avgjørelser. ${ }^{4}$ Objektivitet er således et av rettssikkerhetens mest fundamentale prinsipper og er sentralt både på normnivå og i utdanningen av etterforskere, herunder i norsk politis avhørsmetodikk KREATIV. ${ }^{5}$

Kjelby påpeker at for påtalemyndigheten gjelder objektivitetskravet for den «totale befatningen med saken - både forut for og under etterforskingsfasen, på påtalestadiet og under og etter iretteføring». ${ }^{6}$ Han understreker at dette ikke bare gjelder i den formelle aktorrollen, men også for de vurderinger og beslutninger som tas.

Hensynet til fornærmede er ikke direkte nevnt i Straffeprosesslovkomiteens innstilling av 1969:

«Ved siden av hensynet til sakens oppklaring skal det også tas rimelig hensyn til vitnet. Det betyr at vitnet skal spares for unødig påkjenning eller sjikane. De ubehageligheter som er nødvendige for å få frem sanningen, må de naturligvis finne seg i.»

I 1969 var fornærmede et vitne uten særlig stilling eller rettigheter. Siden den gang er fornærmedes og etterlattes stilling blitt vesentlig styrket. ${ }^{7}$ Ifølge Myhrer er det:

«snakk om en holdningsendring i politiet og påtalemyndigheten: Fra å se på fornærmede som et sentralt vitne uten rettigheter, til at fornærmede skal anses for å ha semi-prosessuell partsstatus med viktige rettigheter.» ${ }^{8}$

\footnotetext{
2 Det Norske Akademis Ordbok, NAOB.no

${ }^{3}$ Gert Johan Kjelby, Påtalerett, Oslo 2017, s. 241.

${ }^{4}$ NOU 2016: 24 avsnitt 8.3.4.

${ }^{5}$ KREATIV vil bli beskrevet i kap. 2.2 .

${ }^{6}$ Gert Johan Kjelby, Påtalerett, Oslo 2017, s. 245.

${ }^{7}$ Straffeprosessloven av 7. mars 2008 nr. 5.

${ }^{8}$ Tor-Geir Myhrer, Kvalitet i etterforskningen, PHS Forskning 2015: 1, Oslo 2015, s. 103.
} 
Endringene betyr bl.a. at fornærmede har fått en rekke nye informasjonsrettigheter på etterforskningsstadiet, og at politiet skal oppnevne en kontaktperson for fornærmede som har ansvar for at fornærmede og etterlatte får den informasjon de har krav på. ${ }^{9}$

Bistandsadvokatordningen ble også betydelig utvidet. Av straffeprosessloven (strpl.) § 107 fremgår det hvem som har rett til bistandsadvokat, og hvordan denne skal ivareta fornærmedes interesser. ${ }^{10}$ Utover påtaleinstruksens (pi.) § 8-11 har endringene ikke direkte innflytelse på hvordan politiet skal avhøre fornærmede. I politiets opplæring og i forskningslitteraturen understrekes imidlertid viktigheten av å møte den avhørte med empati og respekt samt det å opprettholde en god kontakt gjennom hele avhøret.

Objektivitetskravet skal være styrende for måten bevis innhentes på. Kjelby påpeker at valg av metoder og gjennomføringen av etterforskingsskritt må ha som mål «å innhente og sikre pålitelig og objektiv informasjon, både fra vitner, fornærmede og mistenkte/siktede». ${ }^{11}$ Kravet om objektiv saksbehandling nevnes ofte i forbindelse med siktedes/tiltaltes rettssikkerhet, men objektivitet i forbindelse med avhør av fornærmede nevnes sjelden eksplisitt i rettskildene.

Forskning på objektivitet i avhør av siktede har vist hvordan manglende objektivitet kan lede til tunnelsyn og justisfeil. ${ }^{12}$ Objektivitet i avhør av fornærmede er derimot et lite utforsket område, og i lovgivningen og i politiets opplæring er det kun overfladisk skissert hvordan man håndterer det å være både objektiv og empatisk i avhør av fornærmede.

I denne artikkelen redegjør vi først for objektivitetskravets rettslige forankring. Deretter redegjør vi for hvordan det blir tatt hensyn til objektivitet i politiets avhørsmetodikk. Denne beskrivelsen vil danne bakgrunn for en empirisk analyse av 19 lyd- og bildeavhør av 19 fornærmede som overlevde terrorangrepet på Utøya 22. juli 2011, samt intervjuer med de 17 etterforskerne som gjennomførte disse avhørene. Formålet med undersøkelsen er å besvare følgende forskningsspørsmål:

\section{Hvordan praktiserer etterforskere objektivitetskravet når de avhører fornærmede?}

\footnotetext{
${ }^{9}$ Påtaleinstruksen kap. 7A.

${ }^{10}$ For mer om fornærmedes og etterlattes styrkede rettsstilling, se Anne Robberstad, Bistandsadvokaten, Oslo 2014.

${ }^{11}$ Gert Johan Kjelby, Påtalerett, Oslo 2017, s. 247.

${ }^{12}$ Blant annet Saul Kassin, Christine Goldstein og Kenneth Savitsky, «Behavioral Confirmation in the Interrogation Room: On the Dangers of Presuming Guilt», Law and Human Behavior 2003 (27), s. 187-203; Richard A. Leo, Police Interrogation and American Justice, Cambridge 2008; Gisli Gudjonsson, The Psychology of Interrogation and Confession. A Handbook, Chichester 2003; Asbjørn Rachlew, Justisfeil ved politiets etterforskning-noen eksempler og forskningsbaserte mottiltak, doktoravhandling, Det juridiske fakultet UiO, Oslo 2009.
} 
I vår forståelse av «praktiserer» ligger både måten etterforskerne avhører på, og hvordan de forstår og reflekterer over fremgangsmåten.

Når vi ser på måten avhørene gjennomføres på, kommer vi også til å behandle hvordan kommunikasjonen mellom avhører og den avhørte foregår.

I en tidligere studie ${ }^{13}$ ble det samme materialet som er anvendt i denne studien, analysert. Resultatet viste at avhørerne først og fremst oppfattet seg selv som informasjonsinnhentere, men det viste også at de ønsket å utvise empati og medmenneskelighet under avhøret. Objektivitetskravet var sentralt for deres avhørspraksis, men kunne samtidig oppleves som en begrensning for $\varnothing$ nsket om å være støttende og empatisk.

Antaki mfl. har undersøkt hvordan britisk politi håndterer de to potensielt motstridende kravene om objektivitet og empati når de avhører personer med utviklingshemming som anmelder seksuelle overgrep. ${ }^{14}$ Resultatet viste at avhørerne var tilbakeholdne med å vise forståelse, og at de var bevisste på å opptre upartisk ettersom personer med utviklingshemming er mer påvirkelige enn andre. Avhørerne var derfor oppmerksomme på at det kunne stilles spørsmål ved den fornærmedes forklaring hvis de utviste for mye empati.

I Norge har Riis-Johansen analysert 11 avhør av fornærmede i saker om seksuelle overgrep, vold eller voldtekt. ${ }^{15}$ Studien viser hvordan avhørerne kan oppleve forskjellige typer dilemmaer. Riis-Johansen har bl.a. identifisert et dilemma mellom å være nøytral og kritisk undersøkende på den ene siden og å utvise tillit og empati på den andre. Riis-Johansen fremhever at dette dilemmaet kan være særlig utfordrende i saker hvor det er mistanke om seksuelle overgrep, og henviser til intervjustudier og medieomtale som viser at mange fornærmede opplever det som viktig å bli trodd. Samtidig må avhørerne forholde seg til at falske forklaringer kan forekomme. ${ }^{16}$

Kravet om objektivitet i etterforskningen er sentralt uansett hvem som avhøres, og de studier vi her har henvist til, peker på at objektivitetskravet har betydning for hvordan avhøret gjennomføres. Men dette kravet kan føre til dilemmaer når avhører samtidig ønsker å utvise

\footnotetext{
${ }^{13}$ Kristina K. Jakobsen, Åse Langballe og Jon-Håkon Schultz, «Trauma-exposed young victims: possibilities and constraints in providing trauma support within the investigative interview», Psychology, Crime \& Law 2016, s. 427-444. DOI: doi.org/10.1080/1068316X.2016.1269903.

${ }^{14}$ Charles Antaki mfl., "Dealing with the distress of people with intellectual disabilities reporting sexual assault and rape», Discourse Studies 17(4) 2015, s. 415-432.

${ }^{15}$ Marit Olave Riis-Johansen, Balanseganger: En samtaleanalytisk studie av politiavhør av voksne fornærmede, doktoravhandling, NTNU 2016, s. 176.

${ }^{16}$ Ibid., s. 182-183.
} 
empati i avhørssituasjonen. Vi vil derfor i analysen av materialet og i diskusjonen ha fokus på disse potensielle dilemmaene.

\section{Objektivitetskravets rettslige forankring}

\subsection{Den rettslige regulering av objektivitetskravet}

Objektivitetskravet nevnes både i internasjonale konvensjoner og i norske lover, instrukser og direktiv som regulerer avhør.

Internasjonalt kan det vises til formålsbestemmelsen i Den internasjonale torturkomiteens (CPT) standard punkt 34:

«The questioning of criminal suspects is a specialist task which calls for specific training if it is to be performed in a satisfactory manner. First and foremost, the precise aim of such questioning must be made crystal clear: that aim should be to obtain accurate and reliable information in order to discover the truth about matters under investigation, not to obtain a confession from someone already presumed, in the eyes of the interviewing officers, to be guilty. In addition to the provision of appropriate training, ensuring adherence of law enforcement officials to the above-mentioned aim will be greatly facilitated by the drawing up.» ${ }^{17}$

CPT presiserer at hovedformålet med avhør av mistenkte er å frembringe nøyaktig og pålitelig informasjon om saken, og ikke å forsøke å få den mistenkte til å tilstå.

Objektivitetskravet er videre forankret i Den europeiske menneskerettskonvensjonen (EMK) artikkel 6:

«For å få avgjort sine borgerlige rettigheter og plikter eller en straffesiktelse mot seg, har enhver rett til en rettferdig og offentlig rettergang innen rimelig tid ved en uavhengig og upartisk domstol opprettet ved lov. [...] Enhver som blir siktet for en straffbar handling, skal antas uskyldig inntil skyld er bevist etter loven.»

Nasjonalt er objektivitet forankret i den norske Grunnloven § 95:

\footnotetext{
${ }^{17}$ European Committee for the Prevention of Torture and Inhuman or Degrading Treatment or Punishment (CTP), “Extract from the 12th General Report [CPT/Inf (2002) 15]", CTP Standards, CPT/Inf/E (2002) 1 - Rev. 2011 English, p. 9.
} 
«Enhver har rett til å få sin sak avgjort av en uavhengig og upartisk domstol innen rimelig tid. Rettergangen skal være rettferdig og offentlig. [...] Statens myndigheter skal sikre domstolenes og dommernes uavhengighet og upartiskhet.»

Krav om objektivitet er også forankret i domstollovens kapittel 6 som sier at ingen dommer kan være ugild.

Straffeprosessloven $\S 226$ angir det overordnede etterforskningsformålet, og tredje ledd slår fast at etterforskningen skal være objektiv: «Er en bestemt person mistenkt, skal etterforskingen søke å klarlegge både det som taler mot ham og det som taler til fordel for ham.»Videre er det presisert i strpl. $§ 55$ fjerde ledd at «[p]åtalemyndighetens tjenestemenn skal opptre objektivt $\mathrm{i}$ hele sin virksomhet, herunder på etterforskingsstadiet, når det treffes påtalevedtak og ved iretteføring av saken».

Påtalemyndighetens objektive og upartiske stilling under etterforskningen, herunder at avhøret skal gjennomføres objektivt uten noen føringer, er regulert i pi. § 8-2 andre ledd:

«Avhøringen skal skje på en måte som er egnet til å få en så vidt mulig sammenhengende forklaring om det forhold saken gjelder. Mistenkte skal gis anledning til å gjendrive de grunner mistanken beror på, og anføre de omstendigheter som taler til fordel for ham.»

Videre heter det i tredje ledd at «[s]pørsmål må ikke stilles slik at noe som ikke er innrømmet forutsettes som erkjent av mistenkte».

Avhør av fornærmede og etterlatte følger reglene om avhør av vitner så langt det passer iht. pi. § 8-8. Ved denne type avhør skal tjenestemannen iht. pi. § 8-11 sjette ledd alltid «opptre rolig og hensynsfullt og foreta avhøret på en måte som er egnet til å fremkalle en klar og sannferdig forklaring som tar rimelig hensyn til vitnet». For avhør av vitner, fornærmede eller etterlatte under 16 år gjelder særskilte regler regulert i pi. § 8-12.

Straffeprosesslovutvalget nedsatt i 2014 fant det klart at en ny straffeprosesslov bør inneholde en uttrykkelig regulering av objektivitetsplikten. ${ }^{18}$ Utkastet $§ 2-3$ (1) er basert på strpl. § 55: «Påtalemyndigheten skal opptre objektivt i hele sin virksomhet.»

\footnotetext{
${ }^{18}$ NOU 2016: 24 avsnitt 8.3.4.
} 
Med «objektivt» sikter Straffeprosesslovutvalget til at virksomheten skal være saklig og uten egeninteresse utover det som følger av lovens oppgaver. Formuleringen i strpl. $§ 55$ fjerde ledd om at objektivitet skal ivaretas «på etterforskingsstadiet, når det treffes påtalevedtak og ved iretteføring av saken», er foreslått erstattet med «i hele sin virksomhet». ${ }^{19}$

Straffeprosesslovutvalget peker videre på at objektivitetsplikten under etterforskningen bør reguleres særskilt. ${ }^{20}$ Sentralt her er at objektivitetsplikten på dette stadium strekker seg utover en plikt for påtalemyndigheten idet den gjelder for enhver som utfører etterforskning på påtalemyndighetens vegne; dette er formulert i utkastet $§ 13-5$ (1):

«Etterforskingen skal være objektiv. Både det som taler mot og det som taler til fordel for en mistenkt søkes klarlagt. Etterforskingen skal være så hensynsfull som mulig, herunder slik at ingen unødig utsettes for mistanke eller ulempe.»

De føringer som er gitt i strpl. $\S 55$ og 226 tredje ledd, suppleres av Riksadvokatens direktiv og rundskriv, hvor objektivitetskravet de senere årene er gitt en langt mer fremtredende plass enn tidligere.

Kontroll med at objektivitetskravet i strpl. $§ 226$ tredje ledd overholdes, er et sentralt ledd i den påtalemessige ledelse og kontroll med etterforskningen. ${ }^{21}$ Myhrer understreker at «i saker av noe omfang må det derfor være etablert rutiner som sikrer at den påtalemessig ansvarlige kan føre tilsyn med at etterforskingen tilfredsstiller straffeprosesslovens krav». ${ }^{22}$

I 2012 la en arbeidsgruppe frem rapporten Avhфr av sarlig sårbare personer i straffesaker. ${ }^{23}$ I denne rapporten er objektivitet ikke omtalt direkte, men i rundskrivet om tilrettelagte avhør som gjelder avhør av vitner under 16 år og vitner med psykisk utviklingshemming eller annen funksjonsnedsettelse (strpl. § 239) - viser Riksadvokaten til den generelle objektivitetsplikten ved avhør:

«Påtalemyndighetens generelle objektivitetsplikt følger av straffeprosessloven $§ 55$ fjerde ledd og $§ 226$ tredje ledd. Riksadvokaten understreker at denne også gjelder i tilfeller hvor det tilrettelagte avhøret følges av forsvarer. Straffeprosesslovens

\footnotetext{
${ }^{19} \mathrm{Ibid}$.

20 Ibid.

${ }^{21}$ Jf. Riksadvokatens rundskriv av 22.12.1999 (Del II - 3/1999 om etterforsking pkt. V).

22 Tor-Geir Myhrer, «Etterforskingsbegrepet», Tidsskrift for strafferett 1/2001, s. 27.

${ }^{23}$ Justis- og beredskapsdepartementet, Avhør av særlig sårbare personer i straffesaker: Rapport fra arbeidsgruppe, Oslo 2012.
} 
påbud til retten om å våke over at avhøret skjer på en måte som er egnet til å fremkalle en klar og sannferdig forklaring og om å unngå ledende spørsmål, jf. § 136, gjelder tilsvarende for avhørsleder, jf. $§ 239$ a første ledd tredje punktum.» ${ }^{24}$

Objektivitetskravet er gjentatt i Riksadvokatens rundskriv om politiavhør:

«Objektivitetskravet, forankret i EMK artikkel 6 og nedfelt i straffeprosessloven $\S \S 226$ tredje ledd og 55 fjerde ledd, står sentralt ved all straffesaksbehandling. Politiets og påtalemyndighetens objektivitetsplikt skal etterleves gjennom kvalitativt gode avhør som klarlegger det som taler både for mistenktes skyld og uskyld, og som belyser momenter som er av betydning for straffeutmålingen. [...] Det overordnede målet er å innhente relevant og pålitelig informasjon på en adekvat og effektiv måte.» ${ }^{25}$

Riksadvokaten presiserer at «[n]orsk avhørsmetodikk baserer seg på vitenskapelig forankrede metoder for pålitelig og objektiv informasjonsinnsamling fra vitner, fornærmede og mistenkte/siktede, og er i stadig utvikling». ${ }^{26}$ I dette generelle utsagnet om objektiv informasjonsinnhenting inkluderes fornærmede. I samme rundskriv understrekes det at avhør skal skje så nøytralt som mulig slik at den avhørte påvirkes minst mulig.

«Avhør er et bevis som er sårbart for ulike påvirkningsfaktorer, og informasjonsinnhentingen skal i størst mulig grad skje uten at den avhørte påvirkes. Det er derfor viktig ikke bare å konsentrere seg om selve informasjonen, men også på hvordan den er innhentet. Dette vil ha betydning for vurderingen av opplysningenes bevisverdi.» ${ }^{27}$

Av Riksadvokatens etikkrundskriv fremgår det at «[p]åtalemyndigheten skal opptre objektivt i hele sin virksomhet, herunder på etterforskingsstadiet, når det treffes påtalevedtak og ved iretteføring». ${ }^{28}$

\footnotetext{
${ }^{24}$ Ra 2015/00483-18.

${ }^{25}$ Ra $2 / 2016$ I.

${ }^{26}$ Ibid.

${ }^{27}$ Ra $2 / 2016$ II.

${ }^{28}$ Ra 2/2017 - Etiske retningslinjer for medarbeidere i påtalemyndigheten, retningslinje nr. 3.
} 
Selv om objektivitetskravet ved avhør av fornærmede ikke omtales eksplisitt alle steder i lovgivning og teori, er det de vanlige reglene og kravene om objektivitet som gjelder på normnivå. Kjelby sammenfatter påtalemyndighetens objektivitetsplikt på følgende måte:

«Påtalemyndighetens objektivitetsplikt formuleres gjerne som et krav om at påtalemyndigheten skal være objektiv og ha en upartisk stilling på alle trinn av straffesakens behandling. Et krav til upartiskhet og saklighet fremheves regelmessig som kjernepunktet i objektivitetsprinsippet. En presis sammenfatning av både etatens egne yrkesideal og andres forventinger er et krav om at påtalemyndigheten 'opptrer objektivt, uavhengig, selvstendig og samvittighetsfullt'.» ${ }^{29}$

Flere teoretikere løfter frem at prinsippet kan være vanskelig å etterleve. Andenæs skriver:

«Men det er klart at for en ivrig etterforsker er det ikke alltid lett å tilfredsstille den ideale fordring om fullstendig objektivitet. Har man først gjort seg opp en mening om saken, er det ikke mer enn menneskelig at hans interesse særlig vil være rettet mot alt som kan tjene til å styrke hans hypotese.» ${ }^{30}$

I tråd med dette skriver Myhrer:

«Like stor enighet som det er om den ideelle normen om objektivitet, er det like klart at den ikke alltid er like lett å etterleve for den enkelte etterforsker. Særlig vil dette gjøre seg gjeldende i etterforskninger av noe omfang, og som kanskje også er slik at de påkaller sterke følelser.» ${ }^{31}$

Videre peker Myhrer på at straffbare handlinger kan påkalle negative følelser, og fornærmede kan påkalle sympati: «Det er selvsagt en risiko for at slike følelser kan påvirke den objektive siden av objektivitetskravet.» ${ }^{32}$

Som nevnt ble fornærmedes og etterlattes stilling vesentlig styrket gjennom endringene $\mathrm{i}$ straffeprosesslovens kapittel $8 \mathrm{a} \cdot{ }^{33}$ Endringene betyr at politi og påtalemyndighet har en tettere

\footnotetext{
${ }^{29}$ Gert Johan Kjelby, Mellom rett og plikt til straffeforfølgning. Den relative etterforsknings- og påtalepliktens rettslige rammer og rettslige utvikling i norsk straffeprosess, Bergen 2013, s. 320.

30 Johs. Andenæs, Norsk straffeprosess, 4. utgave, samlet utgave ved Tor-Geir Myhrer, Oslo 2009, s. 257.

31 Tor-Geir Myhrer, Kvalitet i etterforskningen, PHS Forskning 2015:1, Oslo 2015, s. 108.

32 Ibid.

${ }^{33}$ Lov 7. mars 2008 nr. 5.
} 
kontakt med dem som er rammet av den straffbare handlingen. Myhrer peker på at det er en latent fare for at dette kan påvirke politiets bestrebelser på å være objektive.

Strandbakken stiller spørsmål ved påtalemyndighetens potensielle utfordring ved objektivitetskravet, og han diskuterer hvorvidt kravet er forenlig med påtalemyndighetens bevisbyrde når det gjelder siktedes skyld. ${ }^{34}$ Rettslig sett er det ikke motstrid. Utfordringen ligger på det psykologiske plan, og Strandbakken spør om den som har bevisbyrden, er i stand til å opptre objektivt.

Ifølge Kjelby er objektivitetsprinsippet i lovgivning og rundskriv tilfredsstillende uttrykt, om enn $\mathrm{i}$ «en fragmentarisk form», slik han uttrykker det. ${ }^{35}$ Temaet for denne artikkelen er å fremskaffe kunnskap om hvordan prinsippet etterleves og praktiseres når politiet avhører fornærmede i straffesaker.

\subsection{Objektivitet i politiets avhørsmetodikk}

I lovgivningen angis de overordnede prinsippene som setter rammene for politiets etterforskning, uten at det angis bestemte metoder for hvordan prinsippene skal etterleves. I dette kapittelet beskriver vi KREATIV - som er norsk politis avhørsmetodikk - med særlig fokus på hvordan denne metodikken forsøker å ivareta objektivitet i avhør. Avslutningsvis beskriver vi hvordan empati mellom avhører og avhørte blir forsøkt ivaretatt ved KREATIV, og hvordan avhører gjennom sin kommunikasjon med avhørte kan utvise empati.

Norsk politi har siden årtusenskiftet profesjonalisert sin avhørsmetodikk, og har etter

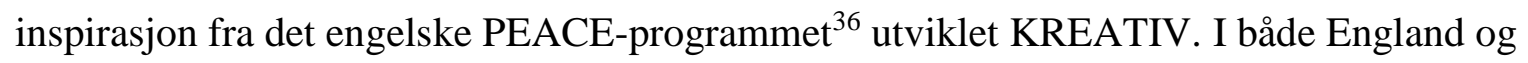
Norge opplevde man saker hvor personer hadde tilstått handlinger de ikke hadde begått, noe som bl.a. ble tilskrevet politiets avhørsteknikker. ${ }^{37}$ Innføringen av KREATIV i 2001 i norsk politi var derfor et bevisst oppgjør med en tilståelsesbasert avhørskultur som preget store deler av politiet. ${ }^{38}$ Formålet med avhøret skal være å få så mye pålitelig og relevant informasjon

\footnotetext{
${ }^{34}$ Asbjørn Strandbakken, Uskyldspresumsjonen - «In dubio pro reo», Bergen 2016, s. 55.

35 Gert Johan Kjelby, Mellom rett og plikt til straffeforfølgning. Den relative etterforsknings- og påtalepliktens rettslige rammer og rettslige utvikling i norsk straffeprosess, Bergen 2013, s. 323.

36 PEACE står for: Planning and Preparation, Engage and Explain, Account, Clarify and Challenge, Closure and Evaluation. 37 En av de mest omtalte sakene i Norge er Karmøy-saken fra 1995 hvor en 19-årig mann tilstod drapet på sin kusine. Han ble først dømt for drapet, men trakk senere tilståelsen tilbake. Etterforskningen ble vurdert av to britiske eksperter som vurderte avhørene av ham som sterkt manipulative, og i 1998 ble han frikjent (se Bjørn Olav Jahr, Hvem drepte Birgitte Tengs?, Oslo 2015, og Gisli H. Gudjonsson, «Drap i Norge: Falsk tro som ledet til falsk tilståelse», Tidsskrift for strafferett 3/2004, s. 287-331).

38 Ivar A. Fahsing og Asbjørn A. Rachlew, «Investigative Interviewing in the Nordic Region», i International Developments in Investigative Interviewing, Cullompton 2009, s. 39-65.
} 
som mulig. Avhørsteknikkene er forskningsbaserte, og særlig psykologisk forskning ${ }^{39}$ har hatt innflytelse på PEACE og KREATIV.

Akronymet KREATIV reflekterer metodikkens verdier og prinsipper, som er:

Kommunikasjon, Rettssikkerhet, Etikk og empati, Aktiv bevisstgjøring, Tillit gjennom åpenhet og Vitenskapelig forankring. Opplæringsprogrammet i KREATIV omfatter en avhørsmodell som består av 6 faser: 1) planlegging og forberedelse, 2) kontaktetablering, 3) fri forklaring, 4) sondering, 5) avslutning og 6) evaluering.

De rettslige rammene for avhøret er implementert i KREATIV. Der henvises det bl.a. til strpl. $\S 226$, pi. § 8-2, Riksadvokatens rundskriv og publikasjoner samt føringer fra CPT.

Påtaleinstruksens $\S 8-2$ andre og tredje ledd understrekes spesielt i KREATIV, da disse på mange måter representerer grunnprinsippene i KREATIV. Andre ledd er i overensstemmelse med vitnepsykologiske prinsipper om viktigheten av upåvirkede frie forklaringer:

«Avhøringen skal skje på en måte som er egnet til å få en så vidt mulig sammenhengende forklaring om det forhold saken gjelder. Mistenkte skal gis anledning til å gjendrive de grunner mistanken beror på, og anføre de omstendigheter som taler til fordel for ham.»

Tredje ledd trekker opp et forbud mot manipulative avhørsteknikker: «Spørsmål må ikke stilles slik at noe som ikke er innrømmet forutsettes som erkjent av mistenkte.»

Objektivitetsprinsippet er sentralt i KREATIV-opplæringen, men anses ikke å være mulig å etterkomme fullt ut. Dette underst $\varnothing$ ttes av omfattende psykologisk forskning som har vist at det ikke er menneskelig mulig å være objektiv. ${ }^{40}$ Man må derimot strebe etter dette normative idealet, bl.a. ved å anvende metoder som motvirker bekreftelsesfeller. Nedenfor beskriver vi hvordan dette er forsøkt løst i KREATIV, ved å beskrive to sentrale temaer i opplæringen. ${ }^{41}$

Beslutningsprosesser, bekreftelsesfeller og taktikkmodellen

\footnotetext{
39 Blant annet Becky Milne og Ray Bull, Investigative Interviewing. Psychology and Practice, Chichester 1999; Eric Shepherd, "Ethical Interviewing», Legal and Criminological Psychology 18/1991, s. 46-56.

${ }^{40}$ Karl Ask og Alison Laurence, «Investigators' decision-making», i Forensic Psychology in Context. Nordic and international approaches, Cullompton 2006, s. 35-55; Linda Lai, Dømmekraft, 5. opplag, Oslo 2007.

${ }^{41}$ Gjennomgangen er basert på undervisningsmateriale fra Politih øgskolens KREATIV-undervisning samt Asbjørn Rachlew og Ivar Fahsing, Politiavhøret i Bevis i straffesaker, Oslo 2015 s. 225-254.
} 
Det første hovedtemaet handler om beslutningspsykologi og hvordan KREATIV bruker kunnskap om dette for å sikre mest mulig objektivitet. Et sentralt begrep er 'bekreftelsesfeller' (confirmation bias), som sikter til en iboende menneskelig tendens til å søke etter, tolke og huske informasjon som bekrefter ens hypotese. ${ }^{42}$ All menneskelig informasjonsbearbeidelse er sårbar for forskjellige former for bekreftelsesfeller. Når det gjelder avhør, vil politietterforskere være særlig sårbare i situasjoner hvor politiet har en konkret mistenkt i en sak. I slike tilfeller kan bekreftelsesfeller påvirke objektiviteten ved en tendens til å a) søke etter informasjon som støtter opp under mistanken, b) tolke ny informasjon i lys av mistanken, c) ta nøytral informasjon til inntekt for etablert oppfatning, og d) ignorere eller bortforklare informasjon som ikke passer inn. Bekreftelsesfeller fungerer ubevisst. Det vil si at på tross av at man som etterforsker forsøker å være objektiv, ikke nødvendigvis er det, og det er derfor objektivitet ikke ansees som menneskelig mulig.

Under avhør av mistenkte benyttes taktikk-modellen, som er et metodologisk fors $\varnothing \mathrm{k}$ på å operasjonalisere uskyldspresumpsjonen. Hypotesetesting er en sentral del av modellen. Den går ut på at alle plausible hypoteser identifiseres og testes. Avhører skal ikke favorisere én hypotese fremfor andre, men behandle alle med samme grundighet. Modellen forventes å redusere faren for ubevisste bekreftelsesfeller ved at den «tvinger» etterforskeren til å utfordre - fremfor å søke å få bekreftet - sin hypotese.

\section{Upåvirkede, pålitelige forklaringer}

Det andre hovedtemaet handler om vitnepsykologi og hvordan kunnskap om dette brukes i metoden for å sikre objektiviteten. Det er gjennomført omfattende eksperimentelle studier som viser at den menneskelige hukommelse ikke er statisk, men påvirkelig og konstruktiv. ${ }^{43}$ Et vitnes minne kan derfor påvirkes av senere informasjon, f.eks. fra politiet i form av lukkede og ledende spørsmål. ${ }^{44}$ Avhøreren må derfor forsøke å minimere sin påvirkning ved primært å benytte åpne spørsmål og så vidt mulig unngå lukkede og ledende spørsmål. I KREATIV vektlegges pålitelighetshierarkiet. Hierarkiet fremstilles visuelt som en trakt, som illustrerer at informasjonens kvalitet normalt er høyest når den avhørte får forklare seg fritt. Jo

\footnotetext{
42 Karl Ask og Alison Laurence, «Investigators' decision-making» i Forensic Psychology in Context. Nordic and international approaches, Cullompton 2006, s. 35- 55.

${ }^{43}$ Se Hilde Østby og Ylva Østby, Å dykke etter sjøhester. En bok om hukommelse, Oslo 2017, og Daniel L. Schacter, The seven sins of Memory, New York 2001.

${ }^{44} \mathrm{Et}$ av de første fors $\varnothing$ kene ble gjennomf $\varnothing \mathrm{rt}$ av Elisabeth Loftus og John C. Palmer og er publisert $\mathrm{i}$ «Reconstruction of automobile destruction: An example of the interaction between language and memory", Journal of Verbal Learning and Verbal Behavior 13/1974, s. 585-589. Gisli H. Gudjonsson har beskrevet suggestibilitet i forbindelse med avh $\varnothing$ r av siktede i The psychology of Interrogations and Confessions. A Handbook, West Sussex 2003.
} 
lenger ned i trakten - dvs. jo mer lukkede, og til sist ledende, spørsmål avhører stiller - jo større er risikoen for at spørsmålene påvirker vitnets forklaring. Idealet er derfor the questionless interview, som vil si at den avhørte helt uten spørsmål forteller om hendelsesforløpet. ${ }^{45}$

Rachlew og Fahsing sammenligner innhenting av bevis gjennom avhør med innhenting av tekniske bevis gjennom åstedsundersøkelser. ${ }^{46}$ Når det gjelder åstedsundersøkelser, har politiet tradisjon og etablerte rutiner for å forebygge kontaminering ${ }^{47}$ av tekniske bevis. På samme måte skal avhører forebygge kontaminering av avhørtes forklaringer ved å minimere antallet spørsmål, særlig dem som er lukkede og ledende.

\section{Empati og kommunikasjon mellom avhфrer og avhфrte}

Viktigheten av å møte den avhørte med empati og respekt - uansett hvem som avhøres understrekes. Avhører kan formidle empati overfor den avhørte ved å være interessert og lyttende, spørre om den avhørtes tilstand og ta den avhørtes situasjon på alvor. Holmbergs forskning viser at både siktede og fornærmede forteller flere detaljer hvis de opplever avhøreren som human (som omfatter å være empatisk og lyttende) fremfor dominerende. ${ }^{48} \mathrm{I}$ KREATIV-metodikken understrekes det at avhører skal forsøke å opprettholde en god kontakt gjennom hele avhøret, men det forklares ikke nærmere hvordan dette gjøres.

I KREATIV-metodikken trekkes det i tillegg på kommunikasjonsteori. Hensikten med dette er bl.a. å utvise empati. Politiavhør tilhører kategorien institusjonelle samtaler - dvs. samtaler som utføres mellom en profesjonell og en lekperson og som har et definert mål. ${ }^{49}$ Rollefordelingen mellom lekperson og profesjonell er i disse samtalene klart definert. Den profesjonelle opptrer på vegne av sin profesjon og representerer en institusjon, og har derfor ansvaret for at samtalen gjennomføres i tråd med de institusjonelle føringene som finnes, og for at oppgaven blir løst. I tillegg har den profesjonelle part kunnskap om institusjonens saksområde og fagbegreper, og han/hun vet hva som er relevant, og hva som ikke er det.

\footnotetext{
${ }^{45}$ Begrepet er introdusert av Ron Fisher som var medutvikler av det såkalte kognitive intervju. Se bl.a. Ronald P. Fisher og R. Edward Geiselman, Memory - enhancing techniques for investigative interviewing. The cognitive interview, Springfield 1992.

${ }^{46}$ Asbjørn Rachlew og Ivar Fahsing, "Politiavhøret», i Bevis i straffesaker. Utvalgte emner, Oslo 2015, s. 239-254.

${ }^{47}$ Med kontaminering menes at det tekniske beviset forurenses. I avhør vil det altså si at avhørtes forklaring blir påvirket av ekstern informasjon. Et kjent eksempel er Lisbet Palmes utsagn når hun etter å ha blitt «tipset» om den mistenktes helsemessige status pekte ut Christer Pettersson som statsminister Palmes drapsmann: «Det ser man väl vem som är alkoholist.»

48 Ulf Holmberg, Police Interviews with Victims and Suspects of Violent and Sexual Crimes. Interviewees' Experiences and Interview Outcome, Stockholm 2010.

49 Per Linell, Samtalskulturer. Kommunikativa verksamhetstyper i samhället, Linköping 2011, s. 572-594.
} 
Under et politiavhør er det avhøreren som er den profesjonelle part, og den avhørte som er lekperson. Ulik kunnskap og den enes rett til å stille spørsmål gir de to aktørene et ulikt utgangspunkt og bidrar til et asymmetrisk maktforhold. For å gi avhørte en forståelse av hva situasjonen innebærer, må avhører forklare måten avhøret gjennomføres på, og avklare roller, rammer og forventninger. På KREATIV-utdanningen lærer avhører å metakommunisere, som vil si å kommunisere om kommunikasjonen. ${ }^{50}$ Tanken bak dette er at man mener at metakommunikasjon gir en rolleavklaring og skaper forutsigbarhet og trygghet i situasjonen.

\section{Metode}

Denne studien er kvalitativ og bygger på et fenomenologisk-hermeneutisk vitenskapsteoretisk ståsted. ${ }^{51}$ Med dette kvalitative perspektivet har studien til hensikt å analysere og beskrive hvordan kravet om objektivitet i avhør blir praktisert. Til grunn for analysen legges både hvordan etterforskerne har gjennomført de 17 avhørene, og deres refleksjoner og faglige begrunnelser for sine fremgangsmåter. ${ }^{52}$ Fremgangsmåtene og forståelsene av objektivitet og empati som er kommet frem gjennom observasjoner og intervjuer av etterforskerne, vil bli analysert i lys av norsk politis avhørsmetodikk og de rettslige rammene for avhør.

\subsection{Datamateriale og fremgangsmåte}

Denne studien bygger på en større studie: Terrorangrepet. Opplevelser og reaksjoner hos de som overlevde på Utøya. ${ }^{53}$ Utøya-studien er longitudinell og består foreløpig av tre runder med forskningsintervjuer. 490 ofre for terrorangrepet den 22. juli 2011 ble spurt om de ville delta i studien, og i den første intervjurunden valgte 325 ungdommer å delta. De ble intervjuet første gang fire til fem måneder etter terrorangrepet. Av de 325 ungdommene hadde 320 blitt avhørt av politiet, de fleste innen to måneder etter terrorangrepet.

\footnotetext{
${ }^{50}$ Kari T. Gamst og Åse Langballe, Barn som vitner. En empirisk og teoretisk studie av kommunikasjonen mellom avhører og barn i dommeravhør: Utvikling av en avhørsmetodisk tilnærming, doktoravhandling, Det utdanningsvitenskapelige fakultet, Universitet i Oslo, Oslo 2004.

51 I fenomenologisk-hermeneutisk orienterte undersøkelser er hensikten å få innblikk i hvordan den enkelte eller spesifikke grupper opplever og forstår verden. I den fenomenologiske tradisjon undersøkes det hvordan et fenomen (her: objektivitetskravet) opptrer for personen/personene, mens man i den hermeneutiske tradisjon også tolker fenomenet i lys av den kontekst det opptrer i (her: den rettslige forankring og politiets opplæring). Hanne Fredlund og Lisa Dahlager, «Kvalitative forskningsmetoder», i Kliniske forskningsmetoder, København 2011, s. 67-88; Susann M. Laverty, "Hermeneutic Phenomenology and Phenomenology: A Comparison of Historical and Methodological Considerations», International Journal of Qualitative Methods 2(3) 2003, s. 21-35.

52 Sigmund Grønmo, Samfunnsvitenskapelige metoder, Bergen 2004, kapittel 13 og 18.

${ }^{53}$ Grete Dyb mfl., "Post-traumatic stress reactions in survivors of the 2011 massacre on Utøya Island, Norway», The British Journal of Psychiatry 14/2014, s. 361-367.
} 
I vår studie ble 30 videoinnspilte politiavhør av fornærmede valgt ut etter følgende kriterier: 1) de yngste, 2) de mest eksponerte for terroren, og 3) de mest traumatiserte. En av de fornærmede var 35 år og var med i materialet ved en feil, men siden etterforskeren i tillegg hadde avhørt flere ungdommer som hadde vært på Utøya under terrorangrepet, valgte vi å beholde dette intervjuet. De $\varnothing$ vrige fornærmede var i snitt 16,9 år ved tidspunktet for politiavhøret.

Gjennom Utøya-studien hadde ungdommene gitt informert samtykke til at det kunne forskes på politiavhørene deres. Riksadvokaten ga tillatelse til å studere de videoinnspilte avhørene, og med tillatelse fra $\mathrm{NSD}^{54}$ ble de 28 etterforskerne som hadde gjennomført de 30 avhørene, kontaktet per brev og e-post og spurt om de ville delta i studien. 18 etterforskere valgte å delta, hvorav to etterforskere hadde gjennomført to av de utvalgte avhørene. Én etterforsker trakk seg fra studien etter forskningsintervjuet. Etterforskerne var mellom 29 og 57 år, ni kvinner og ni menn. De var fordelt på 14 ulike tjenestesteder i Norge. Bortsett fra en enkelt hadde alle gjennomført KREATIV-opplæring, og fire hadde gjennomført studiet «Avhør av barn og ungdommer». 55

Vi har benyttet to datakilder: 19 avhør på lyd og bilde av ungdommer som overlevde Utøyaangrepet og som deltok i Utøya-studien, og 17 kvalitative intervjuer av etterforskerne som gjennomførte disse avhørene.

Før intervjuene med etterforskerne ble lyd- og bildeopptakene av avhørene sett igjennom, og i hvert avhør valgte vi ut 3-4 sekvenser som omfattet (a) den innledende fasen av avhøret (kontaktetableringsfasen), (b) sekvenser hvor den fornærmede forteller om traumatiske opplevelser, (c) sekvenser hvor den avhørte forteller hvordan han/hun følte det under eller etter terrorangrepet, og (d) sekvenser hvor den avhørte virker emosjonelt berørt. Disse sekvensene ble valgt ut fordi vi ønsket å unders $\varnothing$ ke hvordan etterforskerne håndterte både det å være ivaretagende og det å innhente informasjon. Vi antok at disse sekvensene utgjorde situasjoner hvor det ville vært naturlig å opptre støttende overfor den avhørte, men hvor etterforskerne samtidig skulle leve opp til de juridiske krav som ligger i politirollen, herunder objektivitetskravet.

\footnotetext{
54 Prosjektnummeret i NSD (Norsk senter for forskningsdata) er 32150.

55 «Avhør av barn og ungdommer» er et studium ved Politih øgskolens etter- og videreutdanning som tilbys etterforskere som skal gjennomføre tilrettelagte avhør. Studiet utgjør 15 studiepoeng.
} 
Under de kvalitative intervjuene med etterforskerne spilte vi av de utvalgte sekvensene for etterforskerne for å få innblikk i deres refleksjoner og begrunnelser for sine fremgangsmåter. I tillegg ble en spørreguide benyttet. Et sentralt spørsmål i spørreguiden var hvordan man kan ivareta en traumatisert person innenfor rammene av politirollen. Spørreguiden omfattet følgende temaer: (a) hvordan de hadde forberedt seg til avhøret, (b) hvordan de oppfattet sin rolle generelt, og spesielt når de avhører traumatiserte personer, (c) hvordan de opplevde at den avhørte ble påvirket av avhøret, og (d) hvordan de selv ble påvirket av å avhøre traumatiserte personer.

\subsection{Dataanalyse}

For å besvare forskningsspørsmålet har vi bygget videre på en dataanalyse av samme datamateriale $\mathrm{i}$ en tidligere studie. ${ }^{56}$ I den tidligere studien - hvor det ble benyttet tematisk analyse $^{57}$ - forsøkte vi å identifisere hvilken form for støtte etterforskerne mener de som etterforskere kan gi de avhørte fornærmede, og hvilke former for begrensninger de opplever i forhold til å være støttende.

I den tidligere studien ble alle etterforskernes utsagn om begrensninger kodet og deretter delt inn i tre kategorier: 1) manglende kunnskap om traumer og traumereaksjoner, 2) manglende kognitiv kapasitet til både å ha fokus på saken og på den fornærmede, og 3) kravet om objektivitet.

Et hovedfunn var at kravet om objektivitet var sentralt for etterforskernes avhørspraksis, og at det opplevedes som begrensende for $\varnothing n s k e t$ om å være støttende og empatisk. I denne studien er målet å unders $\varnothing$ ke nærmere hvordan objektivitetskravet blir praktisert av etterforskerne når de avhører de fornærmede etter terroren på Utøya.

For å besvare denne studiens forskningsspørsmål ble alle utsagn om objektivitet fra den tidligere studien på ny lest igjennom, og utsagnene ble valgt ut på bakgrunn av vårt teoretiske perspektiv basert på KREATIV og de rettslige rammene for avhør. Deretter ble alle utsagn gruppert i tre ulike måter å praktisere objektivitetskravet på. Alle utsagn om ikke å ta den avhørtes parti og belyse begge sider av saken ble til en kategori, som vi har kalt å vare upartisk. Alle utsagn om ikke å påvirke den avhørtes forklaring ble til en annen kategori, som

\footnotetext{
${ }^{56}$ Kristina K. Jakobsen, Åse Langballe og Jon-Håkon Schultz, «Trauma-exposed young victims: possibilities and constraints in providing trauma support within the investigative interview», Psychology, Crime \& Law 2016, s. 427-444. DOI: doi.org/10.1080/1068316X.2016.1269903

57 Virginia Braun og Victoria Clarke, «Using thematic analysis in Psychology», Qualitative Research in Psychology 3(2) 2006, s. 77-101.
} 
vi har kalt unngå å påvirke. Alle utsagn om å legge personlige holdninger og følelser til side har vi samlet i en kategori som vi har kalt emosjonell distanse.

Under de kvalitative intervjuene fortalte flere etterforskere om potensielle dilemmaer mellom objektivitet og forskjellige hensyn til de fornærmede, som de er opptatt av å håndtere.

Dilemmaene og håndteringen av dem er en konsekvens av objektivitetskravet og er derfor en del av det å praktisere objektivitetskravet. Dilemmaene vil derfor bli beskrevet som en del av de tre fremgangsmåtene. Etterforskernes fors $\varnothing \mathrm{k}$ på å håndtere dilemmaene vil bli presentert $\mathrm{i}$ et eget avsnitt.

\section{Resultater}

Vi har inndelt etterforskernes måter å praktisere objektivitet på i tre kategorier: å vare upartisk, unngå å påvirke og emosjonell distanse. Disse måtene å praktisere objektivitet på beskrives nærmere i det følgende ved hjelp av noen eksemplifiserende sitater fra de kvalitative intervjuene, og i enkelte tilfeller også ved å beskrive enkelte sekvenser fra de videoinnspilte avhørene. Videre beskriver vi dilemmaene etterforskene opplever at deres måte å praktisere objektivitet på kan skape. Til sist i dette kapittelet beskriver vi hvordan etterforskerne fors $ø$ ker å løse de opplevde dilemmaene.

\section{1 Å være upartisk}

Alle etterforskerne forteller at de som etterforskere ikke må ta parti for noen av sakens parter. Dette betyr at de må lytte til begge parters versjon og belyse begge sider like godt. Denne forståelsen er i tråd med lovgivningens intensjon, og flere etterforskere henviser under intervjuet til strpl. $§ 226$ tredje ledd.

Etterforskerne beskriver at de også må stille spørsmål for å forsøke å få klarhet rundt momenter i saken som den avhørte fornærmede ikke forklarer seg om på eget initiativ. Fornærmedes manglende forklaring kan skyldes at fornærmede ikke skjønner at informasjonen kan være relevant, men det kan også være at temaet er ubehagelig for den fornærmede å fortelle om eller dreier seg om forhold som kan så tvil om fornærmedes status i saken. I denne saken var det dog ikke uoverensstemmelse mellom siktedes forklaring, øvrige beviser i saken og de avhørtes forklaringer - de avhørte ungdommene var uten tvil fornærmede i saken. Det var derfor ikke nødvendig å konfrontere dem med andre opplysninger i saken. 
Under forskningsintervjuene forholder flere av etterforskere seg til andre saker enn Utøyasaken og snakker om objektivitetskravet på et mer generelt plan. De skiller ikke mellom avhør av siktede, vitner eller fornærmede når det handler om å være upartisk.

En etterforsker forteller:

«Men i veldig mange andre saker så har jeg det alltid i bakhodet, da, at det kan være en jente eller en gutt som vil skjule at de har vært utro, eller - du vet jo aldri. Det er jo alltid to sider, og gjerne, så er det helt forskjellige forklaringer av hva som har skjedd. Du må jo alltid ha det i bakhodet. Så derfor så må vi også følge alle tråder, spor som kan være skyldfriende for den som er siktet.»

En annen etterforsker forteller:

«Min oppgave er jo ikke å ta stilling til skyld eller ikke skyld, eller ... eller medvirkning, eller mer, da tenker jeg på, altså ... hvilken rolle de har hatt. Men min oppgave er å få frem mest mulig informasjon, og få belyst saken. Det er min oppgave, først og fremst.»

Flere etterforskere sier videre at andre aktører, særlig forsvarsadvokater, kan angripe dem for å være partiske hvis de kun belyser den fornærmedes versjon og dermed kan kritiseres for å ta den fornærmedes parti.

\subsection{Dilemma mellom å være upartisk og å ta hensyn til den fornærmede}

Å være upartisk betyr at etterforskerne ikke kan gi uttrykk for at de tror på den avhørte hvilket begrenser etterforskernes mulighet til å svare på og kommentere det den avhørte forteller. Flertallet av etterforskerne forteller at de kan oppleve et dilemma mellom det å være upartisk og det å ta hensyn til den fornærmede. De beskriver det som et dilemma mellom det å være kritisk og det å ta hensyn til den fornærmedes behov for å bli trodd, hvilket følgende sitat illustrerer:

«Fordi man må være objektiv og man må så også kunne tåle å stille, eller jeg må tørre å stille spørsmål som kanskje kan være ubehagelige for både han, i denne situasjonen, eller barn utsatt for seksuelle overgrep, så må jeg også være kritisk, for å vise at jeg ivaretar objektiviteten.»

En annen etterforsker forteller: 
«Jeg må jo bare være mest mulig nøytral og få vedkommende til å spille på lag med de spørsmålene og det jeg gjør. Og noen vil føle selvfølgelig et konfronterende spørsmål som det er et angrep på vedkommende person - det å ikke bli trodd.»

En tredje forteller:

«... for noen ganger så har jeg opplevd under avhør av voksne, at 'Ja, tror du ikke på meg?', og så sier jeg 'Det er ikke det at jeg ikke tror på deg, men jeg kan på en måte ikke sitte og dømme her og nå hva som er rett og galt i forhold til det som har skjedd. Det må vi ta videre ut over etterforskningen, det må vi finne ut av senere. Vi må jobbe med saken'. Og da er det på en måte greit, men de føler nok ofte at vi kan være litt sånn, når de sitter her og kommer med, de ønsker veldig at vi skal si: ‘jeg skjønner', ‘jeg forstår’, og gi de et klapp på skulderen nesten da.»

Etterforskeren opplever at det på en måte er greit, men er samtidig oppmerksom på at noen avhørte ønsker å bli trodd og få mer forståelse fra etterforskeren. Under intervjuet forteller etterforskeren hvordan hun noen ganger forsøker å løse dilemmaet ved å forklare sin rolle til den avhørte under avhøret, ved f.eks. å si: «Vi kan ikke ta noen stilling til det, men det er ikke fordi jeg tviler på det du sier, men vi må holde oss objektive.» Sitatet viser imidlertid at hun formidler to budskaper som står i motsetning til hverandre, noe som understreker at det er et dilemma mellom objektivitet og hensynet til avhørtes ønske om å bli trodd. Eksemplet peker også på at etterforskerne forsøker å løse dilemmaet, men at disse løsningene ikke alltid er tilstrekkelige.

\subsection{Unngå å påvirke}

Under avhørene oppfordrer samtlige etterforskere de fornærmede til å fortelle fritt - både i den første, frie forklaringen og i sonderingsfasen når forskjellige temaer skal utdypes. I noen få tilfeller stiller etterforskerne utdypende spørsmål underveis i den frie forklaringen, men uten at dette avbryter den fornærmedes forklaring.

Denne åpne fremgangsmåten anvendes for å få frem mest mulig upåvirket og pålitelig informasjon, og for å sikre objektiviteten ved at det kan komme frem informasjon som endrer etterforskerens oppfattelse. 
En avhører forteller: «Det er jo litt det som går på avhørsmetodikken vår, at man får en åpen og fri forklaring», og videre at det er «[g]enerelt min rolle, og at jeg ikke ville avbryte, jeg ville ikke si for mye, jeg ville være objektiv ...».

En annen etterforsker forklarer:

«Så når jeg sitter med en person og mottar informasjon, så må alltid jeg være åpen for at det kan komme en vesentlig ny opplysning som jeg ikke er kjent med, og som forandrer hele mitt bilde av saken. Så jeg tror egentlig at jeg er innstilt på mottak av sånt.»

\subsection{Dilemma mellom å unngå å påvirke og å respondere på den fornærmedes forklaring}

Denne måten å innhente upåvirket informasjon på kan i noen tilfeller få etterforskerne til å fremstå som distanserte. I noen avhør ses dette mest tydelig når den fornærmede har forklart lenge og detaljert om svært traumatiske opplevelser. Etter disse frie forklaringene venter etterforskeren ofte noen sekunder for deretter å stille utdypende spørsmål.

I et avhør forteller den fornærmede at han var redd for å miste sin venn som han forsøkte å gi førstehjelp. Han avslutter den frie forklaringen med å forklare at han var redd fordi han aldri hadde prøvd å gi førstehjelp tidligere. Deretter er det stille noen sekunder, og etterforskeren begynner da å stille spørsmål om hvor fornærmede fysisk befant seg. Etter å ha sett sekvensen reagerer etterforskeren selv på at denne fremgangsmåten kan virke distansert. Hun forklarer:

«Ja, det kan jo være at det hadde virket litt mer sympatisk om jeg på en måte hadde stilt et oppfølgingsspørsmål eller to i forhold til ham han fryktet skulle dø i fanget hans, og så ... kanskje om han vet hvordan det gikk med ham i ettertid og så kanskje ha vært litt støttende og si: 'Du gjorde jo ditt beste der og da og det du kunne for ham' og kanskje bakket opp litt da. Det hadde sikkert ikke skadet, tenker jeg, når jeg ser det i ettertid.»

Flere etterforskere peker på at de kan oppleve et dilemma fordi bekymringen for å påvirke den fornærmedes forklaring reduserer etterforskerens mulighet til å respondere på det den fornærmede forteller.

En etterforsker forteller: 
«Ja, jeg har jo lyst til å si noe, men samtidig så er poenget med, jeg skal jo sitte der og ta imot det jeg får, og jeg ønsker jo egentlig ikke å avbryte tankerekken hennes heller, når hun sitter og ...»

Etterforskeren forklarer at hun kan vise at hun lytter ved å nikke, men at hun verbalt ikke kan kommentere det den fornærmede forteller og utdyper:

«Ja, igjen da, det går jo på rollen min. Så det at jeg er usikker på hva jeg kan si og ikke, og det er jo nettopp objektivitet, at jeg ikke skal sitte der og begynne å på en måte si at 'Sånn du gjorde der var riktig, og sånn ...' Altså, at jeg skal ikke ha så mye meninger om det da. Jeg skal ta imot, jeg. Så det går nok litt på det. Samtidig, så går det an å vise litt empati, rett og slett. Så jeg gjør jo det til en viss grad ved det er litt dumt at du ikke ser ansiktet mitt, men jeg tror at jeg gjør det til en viss grad med på en måte at jeg er veldig med på det hun sier. Men samtidig, så noen ganger så er ikke det nok.»

\subsection{Emosjonell distanse}

Flere etterforskere forteller at det kan være nødvendig å holde en emosjonell distanse for å kunne ivareta objektiviteten. Denne måten å operasjonalisere objektivitet på kan kanskje forstås som en forutsetning for å kunne ha fokus på informasjonen. Hvis man blir påvirket og involverer seg, kan det hindre at man får belyst begge sider like godt fordi man da kan komme til å være tilbakeholdende med kritiske spørsmål. Samtidig kan fremgangsmåten beskytte etterforskeren mot å bli berørt.

En etterforsker forteller:

«Så man holder jo en sånn viss distanse, for man skal ha en profesjonell rolle oppi det også. Og [2-3 ord uforståelig], så kan man risikere nesten å ødelegge kanskje avhøret også, hvis det - de, man må liksom ... ja, bli en litt sånn balansegang for å klare å holde dem inni den avhørssituasjonen også, at det ikke tar helt ...»

En annen etterforsker forteller: «Jeg skal bare ha frem fakta. Jeg tar det ikke inn over meg, kjenner jeg. Jeg hører bare historien ...» Og en tredje etterforsker forteller:

«Men når jeg involverer meg, må jeg ikke bli blind for fakta. Jeg må ikke bli så engasjert hvordan de har det som personer, så jeg går glipp av det saken dreier seg om. Man må på en måte holde hodet klart og opptre profesjonelt.» 


\subsection{Dilemma mellom emosjonell distanse og emosjonelt nærvær}

Noen av etterforskerne forklarer at de tror det kan være en fordel for den fornærmede at de ikke blir berørte. Fornærmede kan da fortelle alle de grufulle detaljene som han/hun kanskje skåner andre for. Etterforskerne er samtidig oppmerksomme på at deres fremtoning i så måte også kan føre til at den fornærmede kan bli usikker på om etterforskeren har lyttet og forstått. Flere etterforskere omtaler denne distansen etter å ha sett seg selv i de utvalgte sekvensene. En etterforsker opplever at man til og med kan komme til å fremstå som avstumpet fordi man tilsynelatende ikke blir berørt, men har fokus på informasjonen som fremkommer. En annen etterforsker forklarer det på følgende måte:

«Jeg føler meg noen ganger, kanskje, at når hun har fortalt sånn og sånn, og så sitter jeg der helt uttrykksløs. Jeg sitter jo bare og tar inn informasjon, og sitter der helt ... Men jeg synes liksom det er jobben min også, på en måte.»

\subsection{Forsøk på å løse de opplevde dilemmaene}

De vanligste måtene å forsøke å løse de potensielle dilemmaene mellom objektivitet og hensynet til den fornærmede på løser ikke alltid dilemmaet når det oppstår, men kan forebygge at dilemmaet oppleves som sterkt når det oppstår. Alle etterforskerne forteller at de kan utvise forståelse og empati i kontakt- og i avslutningsfasen, og at de forbereder den fornærmede på fremgangsmåten for avhøret. Dette noterte vi oss også at de gjorde da vi så igjennom de videoinnspilte avhørene. Formålet med å utvise forståelse og empati er å skape en trygg og tillitsfull kontakt. Formålet med å forklare fremgangsmåten er å forberede den fornærmede på at det er han/hun som skal fortelle først, og at etterforskeren vil stille mange spørsmål, kanskje også spørsmål som kan oppleves som kritiske.

Flere etterforskere nevner at metakommunikasjon underveis i avhøret kan løse dilemmaene. Ved gjennomsyn av lyd- og bildeopptakene fremgår det at alle etterforskerne forklarer fremgangsmåten i kontaktetableringsfasen, men at få bruker metakommunikasjon under den frie forklaringen og i sonderingsfasen. Det kan virke som om det er en mulighet som etterforskerne er bevisste på, men som de anvender i mindre grad enn de selv tror. En mulig forklaring på at de i så liten grad metakommuniserer i vårt datamateriale, kan være at de fleste fornærmede ikke virket opprørte, og fortalte hva de hadde opplevd på en rolig og detaljert måte. 
En annen løsning flere etterforskere peker på, er å utvise empati ved nonverbale tegn som f.eks. å nikke og se interessert ut. På denne måten formidles støtte samtidig som man formelt ivaretar objektiviteten. ${ }^{58}$

Flere etterforskere gir uttrykk for at disse løsningene ikke alltid oppleves som tilstrekkelige særlig når de observerer seg selv i de utvalgte sekvensene. I tillegg nevner de fleste at dilemmaene ofte vil være mer uttalte i andre saker hvor fornærmede ikke er et så klart definert offer, og hvor hendelsesforløpet er uklart, samt i avhør hvor avhørte fremstår som mer følelsesmessig påvirket.

I noen avhør håndterer etterforskerne dilemmaet ved å respondere på den avhørtes forklaring, og tilkjennegir derved at de har oppfattet det emosjonelle innholdet i forklaringen.

I ett avhør skjer dette etter den frie forklaringen - etterforskeren kommenterer forklaringen ved å si: «Jeg har ikke ord.» Hun forklarer under forskningsintervjuet:

«Du kan jo ikke sitte og høre på og ta imot en sånn historie uten å bli berørt. Og det vil vise på en måte. Ja, du skal jo ikke, du skal ikke ... det er forskjell på det å bryte sammen eller at du ikke klarer å håndtere det, men at du sier noe om det, det tenker jeg er naturlig.»

Denne etterforskeren tilføyer at hun trodde den fornærmede kunne blitt usikker på om hun hadde hørt hva han fortalte hvis hun ikke hadde gitt noen form for tilbakemelding.

I et annet avhør forteller den fornærmede at han flyktet fra gjerningsmannen, og han snakker lenge om at han ikke forstår hvorfor han ikke ble skutt. På slutten av avhøret forteller etterforskeren den avhørte at han handlet riktig ved å flykte fra gjerningmannen da det er vanskelig å treffe en person som løper, og at det antakelig nettopp var fornærmedes handling som reddet livet hans. Etter å ha sett sekvensen forklarer etterforskeren:

«Altså man skal holde seg til fakta, og så har man utgangspunkt i at man skal belyse gjerne straffebud da, og så får det være med det. Og man skal holde sine egne meninger for seg sjøl. Det er hovedregelen. At man mener ikke så veldig mye om det man hører. Men i enkelte tilfelle så mener jeg at det kan være rom for

\footnotetext{
${ }^{58}$ Det ser ut til at avhørerne ikke vurderer det å nikke som å ta stilling, men bare som å være oppfordrende. I mange sammenhenger vil et nikk imidlertid være like konkret som en verbal tilbakemelding.
} 
det ... da er man på en måte ikke inne i en fase på etterforskingen eller i avhøret, hvor du, påvirker hans valg av videre forklaring eller påvirker utfallet. Så jeg tenker det er viktig å skille da hva som er følelser i etterkant, og å sitte med skyldfølelse eller traumer eller hva det er.»

Og han tilføyer:

«... det kan kanskje være godt å høre det fra politiet da. I stedet for at man sitter overfor et stenansikt som ikke viser noen som helst slags følelser. Så lenge man er innenfor ... man skal ikke sitte ... man skal forholde seg til etterforskningen.»

Det fremgår altså at etterforskeren er oppmerksom på når i avhøret og hvilke temaer man kan kommentere. Han tilføyer at det ikke er i alle typer saker han kan kommentere, og nevner som eksempel voldtektssaker:

«Der mener jeg ingenting om det. Det er på en måte mye mere et minefelt å bevege seg ut i. At man gjorde det ene eller det andre. Så det er som du sier: Det kommer veldig an på saken. Så jeg tror det er mye lettere i saker hvor det er åpenbart definert her er man et offer som har vært i et traume.»

Eksemplet illustrerer at det ikke er en enkel vurdering. For at etterforskeren skal føle seg trygg nok til å kommentere, og som han selv formulerer det, «komme med subjektiv betraktning», må det være på slutten av avhøret, temaet må være noe som ikke påvirker valg av videre forklaringer, og det må være snakk om et udiskutabelt offer - noe Utøya-ofrene er.

\section{Diskusjon}

Etterforskerne praktiserer objektivitetskravet på tre ulike måter. De fors $\emptyset$ ker å vare upartiske, unngå å påvirke og holde en emosjonell distanse. Den første måten å praktisere kravet på innebærer at etterforskerne ikke må ta parti med noen av sakens parter, men skal belyse begge sider like godt. De kan derfor ikke «tro på» den fornærmedes versjon, men må stille mange spørsmål som kan oppleves som kritiske og ubehagelige. Denne fremgangsmåten er i overensstemmelse med ordlyden i strpl. § 226 tredje ledd. Den andre fremgangsmåten, forstått som å unngå å påvirke, skal sikre at etterforskerne gjennom etterforskningen får frem sannheten om hva som har skjedd. Etterforskningens grunnleggende formål er således å finne den materielle sannheten, og for å oppnå dette følger etterforskerne politiets avhørsmetodikk som bygger på vitnepsykologisk forskning om avhørerens påvirkningskraft. Etterforskerne 
stiller derfor mange åpne spørsmål, men er tilbakeholdne med å respondere på det den avhørte forteller. Den siste fremgangsmåten handler om emosjonell distanse. Flere etterforskere forteller at de ikke må involvere seg og mene for mye om det de hører, men må holde en emosjonell distanse. Etterforskerne er samtidig oppmerksomme på at dette kan få dem til å fremstå som uberørte og distanserte. Denne siste forståelsen er verken beskrevet $\mathrm{i}$ lovgivningen eller i KREATIV. Det kan altså se ut som om etterforskerne tolker kravet strengere enn de må, og at den siste forståelsen er et uttrykk for en selvpålagt restriksjon som gjør dem i stand til å tre inn i rollen som «objektiv etterforsker». For å klare å ha fokus på å innhente og bearbeide informasjon objektivt, stille alle de ubehagelige spørsmålene og ikke «bli blind for fakta» må man som etterforsker sette følelser til side. Det påvirker hvordan etterforskeren fremstår, og det kan også påvirke kommunikasjonen mellom etterforskeren og fornærmede. Samtidig kan en slik strategi beskytte etterforskeren mot å bli følelsesmessig påvirket.

Avhør er en av politiets mest anvendte etterforskningsmetoder, men i tillegg er det en (institusjonell) samtale mellom to personer. Det gjelder for institusjonelle samtaler at premissene for samtalen er regulert i lover og retningslinjer, og at det er et klart formål med samtalen. I tillegg er politiet opplært i særlige metoder for å gjennomføre avhørssamtaler. Disse lovene og metodene vil påvirke hvordan avhøret foregår. Som beskrevet ovenfor er objektivitetskravet en sentral premiss i politiavhøret.

I KREATIV sammenlignes avhøreren med kriminalteknikeren. For ikke å påvirke kontaminere - et potentielt bevis må kriminalteknikeren ta på seg munnbind og hansker, og på samme måte bør avhøreren beskytte avhørtes forklaring mot påvirkning ved bare å stille åpne spørsmål. Denne fremgangsmåten kan stride mot vanlige kommunikasjonsprinsipper som resiprositet. ${ }^{59}$ Resiprositet refererer til en grunnleggende gjensidighet mellom samtalepartnere og mellom deres bidrag i dialogen. Et banalt eksempel er at hvis A hilser på B, vil A vanligvis forvente at B hilser tilbake. Tilsvarende, hvis A stiller et spørsmål til B, vil A forvente et svar. Når B har svart, vil B på sin side forvente et svar eller en reaksjon fra A. I avhørene skjer det flere ganger brudd på denne gjensidigheten som er vanlig i hverdagskommunikasjon. I noen tilfeller skjer dette etter at den fornærmede har fortalt lenge om traumatiske opplevelser og om følelser som skyld og redsel. Når den fornærmede ikke mottar noen form for respons fra etterforskeren, kan det oppleves som brudd på resiprositeten, og det kan virke negativt da den

\footnotetext{
59 Per Linell og Thomas Luckmann, «Asymmetries in dialogue: some conceptual preliminaries», i Asymmetries in Dialogue, Hemel Hempstead 1991, s. 1-20.
} 
fornærmede kan begynne tvile på om etterforskeren har lyttet og forstått det emosjonelle innholdet. Det som særlig kan hindre opplevelsen av resiprositet, er at etterforskerne sjelden responderer på det den fornærmede forteller, og at etterforskerne dermed kan fremstå som emosjonelt distanserte. Etterforskeren som kommenterte den fornærmedes frie forklaring ved å si «Jeg har ikke ord», virket bevisst på dette. Hun forklarte at hvis hun ikke hadde kommentert den frie forklaringen, kunne den fornærmede ha lurt på om hun hadde hørt og forstått det han hadde forklart.

Et kjennetegn ved institusjonelle samtaler er at den profesjonelle kjenner til fremgangsmåten samt begrunnelsen for fremgangsmåten. ${ }^{60}$ Som den profesjonelle part kjenner politiet altså grunnen til den manglende responsen, mens den avhørte ikke har denne kunnskapen og kan oppleve det som brudd på resiprositeten.

I motsetning til kriminaltekniske unders $\varnothing$ kelser er innhenting av informasjon gjennom avhør samtidig en samtale mellom minst to personer. De to formene for bevisinnhenting kan derfor ikke sammenlignes direkte. I forsøket på ikke å påvirke (ved å være som kriminalteknikeren) kan avhøreren faktisk risikere å påvirke den avhørtes forklaring ved å bryte vanlige kommunikasjonsprinsipper og slik fremstå som distansert, noe som kan ha negative konsekvenser for avhøret.

I KREATIV er det lagt vekt på empati, forståelse og respekt, og etterforskerne fortalte i intervjuene at de ønsket å være støttende overfor ungdommene de avhørte. Resultatene viser at objektivitetskravet reduserer etterforskernes reelle og subjektivt opplevde mulighet til å være støttende og respondere på det den fornærmede forteller. Disse to delvis motstridende hensyn kan føre til at etterforskerne opplever et kommunikativt dilemma. Kommunikative dilemmaer kan oppstå når det er flere og delvis motstridende formål med en samtale.

Dilemmaene oppstår på grunn av premissene for kommunikasjonen samtidig som de påvirker kommunikasjonen og må løses ved hjelp av kommunikasjon i form av et kompromiss mellom de motstridende hensynene. ${ }^{61}$

Etterforskerne er opptatt av å finne løsninger på disse kommunikative dilemmaene. Flere peker på løsninger i form av nonverbal kommunikasjon og metakommunikasjon - hvor man bl.a. forklarer fremgangsmåten i begynnelsen av avhøret for å skape forutsigbarhet - og at

\footnotetext{
60 Per Linell, «De institutionaliserade samtalens elementära former: om mötet mellan professionella och lekmän», Forskning om utbildning 17, 1990:4, s. 18-35.

61 Per Linell, Samtalskulturer. Kommunikativa verksamhetstyper i samhället, Linköping 2011, s. 572-594.
} 
man utviser empati og forståelse først og sist i avhøret. Problemet med dette er imidlertid at behovet for støtte kan oppstå i informasjonsinnhentingsfasen når den fornærmede forteller om traumatiske opplevelser - altså i den fasen hvor etterforskerne nettopp er opptatt av å være objektive og ikke påvirke den fornærmedes forklaring.

Som nevnt i innledningen er hvordan man håndterer både det å være objektiv og å være empatisk, kun overfladisk skissert i lovgivningen og i politiets opplæring. Det blir dermed opp til den enkelte å håndtere dilemmaene. I vårt materiale ser det ut til at vekten på objektivitet og påvirkningskraft kan føre til at man er engstelig for ikke å være «objektiv nok», og det sikreste kan bli å utvise en streng form for objektivitet og ikke kommentere eller utvise empati i det hele tatt i de fasene av avhøret hvor man innhenter informasjon om saken.

Hvor sterkt dilemmaene oppleves, avhenger dels av avhørerens rolleforståelse, sensitivitet og evne til å håndtere dilemmaene, og dels av fornærmedes forventninger og sakens karakter. I denne saken hadde ungdommene overveiende positive opplevelser av å bli avhørt. De var rolige og fortalte detaljert om sine opplevelser, og mange følte en samfunnsmessig forpliktelse til å hjelpe politiet. ${ }^{62}$ I tillegg er saken spesiell fordi skyldspørsmålet var avklart. I saker hvor den fornærmede ikke så åpenbart er definert som offer, kan det derimot oppleves som mer utfordrende å balansere mellom objektivitet og empati. Mange av etterforskerne nevner voldtektssaker som eksempel på dette.

\subsection{Styrker og svakheter}

Datamaterialet er spesielt fordi gjerningsmannen var pågrepet og skyldspørsmålet avklart. Det var derfor ikke tvil om ungdommenes status som fornærmede - i motsetning til i mange andre saker hvor skyldspørsmålet er uavklart under etterforskningen og offerrollen derfor mindre tydelig. I tillegg er det snakk om sterkt traumatiserte ungdommer som hadde hele det norske folks sympati. ${ }^{63}$ Det at denne saken skiller seg fra andre saker, kan ses som en begrensning ved denne studien, og et videre forskningsprosjekt kunne være å se på spenningen mellom empati og objektivitet $\mathrm{i}$ andre saker hvor det er uklart om det er begått en straffbar handling,

\footnotetext{
62 Ungdommene ble som beskrevet intervjuet 4-5 måneder etter terrorangrepet, og ble bl.a. spurt om hvordan de opplevde det å gjennomgå politiavhør. De fleste sa at det ikke var belastende eller kun litt belastende å bli avhørt av politiet (72\%), mens $28 \%$ opplevde avhøret som belastende i st $\varnothing$ rre eller mindre grad. For mer informasjon om ungdommenes erfaringer med å bli avhørt, se Åse Langballe og Jon-Håkon Schultz, «l couldn't tell such things to others: Trauma-exposed youth and the investigative interview», Police Practice and Research: An International Journal 2016, s. 62-74. DOI: doi.org/10.1080/15614263.2016.1229185

${ }^{63}$ Siri Thoresen mfl., «The day Norway cried: Proximity and distress in Norwegian citizens following the 22nd July 2011 terrorist attacks in Oslo and on Utøya Island», European Journal of Psychotraumatology, 3(1), 2012. DOI: doi.org/10.3402/ejpt.v3i0.19709
} 
og hvor det er uklart hvem som er gjerningsmannen. Vi mener likevel at resultatene kan overføres til andre saker hvor det er sannsynlig at fornærmede har opplevd traumer og spenningen mellom empati og objektivitet dermed vil være mer uttalt. En styrke ved denne studien er at vi både har hatt tilgang til de videoinnspilte avhørene og har intervjuet etterforskerne som gjennomførte dem. I tillegg har vi kunnskap om hvordan ungdommene opplevde å gjennomgå avhørene. Dette materialet har gitt mulighet til å få inngående kunnskap om avhørene som er studert. Ved å spille av sekvensene under forskningsintervjuene har vi fått innsikt i avhørernes refleksjoner om de spesifikke situasjonene. Samtidig kan dette også ha vært en svakhet ettersom etterforskerne kan ha opplevd forskningsintervjuet som en evaluering, noe som kan ha begrenset hvor åpent de har fortalt om sine avhørspraksiser. ${ }^{64}$

\subsection{Konklusjon}

I denne studien har vi identifisert forskjellige måter å praktisere objektivitetskravet på, og disse er delt inn i tre kategorier: å vare upartisk, unngå å påvirke og emosjonell distanse. Felles for de tre er at de kan begrense etterforskernes mulighet til å kommentere det den fornærmede forteller, og det kan gjøre at etterforskerne i noen tilfeller virker distanserte under avhør. Samtidig ønsker etterforskerne å utvise forståelse og empati for den fornærmede. Dette kan skape en rekke kommunikative dilemmaer under avhør. Etterforskerne som deltok i denne studien, kunne i stor grad løse og forebygge potensielle kommunikative dilemmaer ved innledningsvis å skape en trygg og tillitsfull kontakt og forberede de fornærmede på fremgangsmåten. I flere avhør oppstår det imidlertid situasjoner hvor etterforskeren opplever dilemma, og hvor fremgangsmåten er i konflikt med vanlige kommunikasjonsprinsipper. De fleste etterforskerne peker på at de kommunikative dilemmaene vil være mer uttalt i saker hvor hendelsesforløpet er mer uklart, og mange nevner voldtektssaker som eksempel på dette. Objektivitetskravet er en fundamental norm og står sentralt i politiets avhørspraksis, men som resultatene i denne studien viser, kan kravet oppleves som begrensende i forhold til å ivareta den avhørte, og etterforskerne kan komme til å fremstå som distanserte. Dette understreker

\footnotetext{
${ }^{64}$ Dette er muligvis blitt forsterket av forfatternes erfaring og tilknytning til avhørsutdanninger. Førsteforfatteren, som har foretatt de fleste intervjuene, er fagansvarlig for avhørsutdanninger på Etter- og videreutdanningen ved Politih $\varnothing g s k o l e n$. Tredje forfatter, som har gjennomført en mindre del av intervjuene, har sammen med Kari Gamst utviklet den norske modellen for avhør av barn (DCM), og har gjennom mange år undervist ved Politihøgskolen på studiet «Avhør av barn og ungdom».
} 
behovet for fokus på hvordan man som etterforsker kan praktisere objektivitetskravet og samtidig være empatisk i avhør av fornærmede. 